原著

肝硬変による食道静脈瘤の手術危険度の凝固・線溶学的検討

愛媛大学医学部第 2 外科（主任：木村 茂教授）

$\begin{array}{lllllll}\text { 佐 } & \text { 藤 } & \text { 通李正男 久 保周 } \\ \text { 木 } & \text { 村 } & \text { 茂 } & & & & \end{array}$

愛媛大学医学部中央手術部

永 井勲

\title{
COAGULATION AND FIBRINOLYTIC STUDIES ON OPERATIVE RISK OF ESOPHAGEAL VARICES WITH LIVER CIRRHOSIS
}

Motomichi SATO, Masao LEE, Meguru KUBO and Shigeru KIMURA

2nd Department of Surgery, Ehime University School of Medicine

(Director : Prof. Shigeru KIMURA)

Isao NAGAI

Operation Center of Ehime University Hospital

凝固・線溶系因子の多くは肝で産生される turn over の速い蛋白であるため，凝血能 は肝予備力を反映する。 今回肝硬変による食道静脈瘤直達手術 21 例を, 術後経過に上り 合併症非発生群13例, 合併症発生群 4 例（重症浮腫, 肝膿瘍, 消化管出血, 肺炎など), 合併症死群 4 例 1 肝不全) に分け, さらに術後黄㾞発生の有無により, 術前凝血能を比 較検討し，手術危険度を判定した。凝血学的検査はAPTT (sec), PT (\%), fibrinogen $(\mathrm{Fbg})$, FDP $(\mu \mathrm{g} / \mathrm{ml})$, antithrombin III (ATIII) - plasminogen $(\mathrm{Plg}) \cdot \alpha_{1}$ antitrypsin $\left(\alpha_{1} \mathrm{AT}\right) \cdot \alpha_{2}$ macroglobulin $\left(\alpha_{2} \mathrm{M}\right)(\mathrm{mg} / \mathrm{dl}), \alpha_{2}$ plasmin inhibitor $\left(\alpha_{2} \mathrm{PI}\right)$, 血小板数 (plat) $\left(10^{4} / \mathrm{mm}^{3}\right)$ を行なった.

1）食道静脈㾇患者はいずれも著しい凝血学的異常にあったが, 術後黄庭発生例では APTT, Fbg, ATIII な゙で、合併症死例ではFDP, ATIII, $\alpha_{2} \mathrm{M}, \mathrm{plg}, \alpha_{2} \mathrm{PI}$ がより異常值 をとった。

2）手術安全域は APTT $<40, \mathrm{PT}<70, \mathrm{Fbg}>200, \mathrm{ATIII}>16$ ，比較的危険域（㭪後 黄疾発生）はAPTT $>44, \mathrm{PT}<60, \mathrm{Fbg}<170, \mathrm{ATIII}<15$ ，絶対的危険域（㭪後合併症 死）は FDP $>5, A T I I I<12, \mathrm{Plg}<5 ， \alpha_{2} \mathrm{PI}<58$ とら一応の基隼が得られた。

以上上り術前凝血能は, 術後黄百発生, 耐術の可否の判定に有用であると思われる.

索引用語：食道静脈瘤, 凝固・線容系, 肝硬変, 肝予備力

はじめに

門脈圧穴進症 (門六症) の患者では肝機能障害を合 併することが多く，種々の障害を合併するのが常であ り，このよらな症例に手術を行らと術後合併症が発生 しやすい，食道静脈瘤に対する手術危険度には肝障害 の程度が関係し, 従来より肝機能検查値より種々の検 討がなされている122．肝疾患では凝固・線容系の異常 が認められることが知られているが34)，凝固・線溶系
因子の大多数は肝で産生される turn over の速い蛋白 であるため, 肝の蛋白合成能の指標となり，肝予備力 を反映する。プロトロンビン時間, へパプラスチンテ ストなどが門穴症に対する手術危険度の判定に一般的 に使われている゙2.

しかしながら食道静脈瘤の手術危険度と凝血能に関 する詳細な報告は少ない．また肝障害を伴わない特発 性門穴症では術後の重篤な合併症は少ない，そこで今 
表 1 肝硬变合併食道举眼嘴手術症例

\begin{tabular}{|c|c|c|c|c|c|c|}
\hline & 被行手甫 & 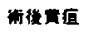 & & 消榙 & 合脌撞 & 此 \\
\hline \multirow{13}{*}{$\begin{array}{c}1 \\
(n=13)\end{array}$} & $a-T r+$ Dev $+5 p$ & - & & & - & 生 \\
\hline & $"$ & - & & & - & $"$ \\
\hline & $u$ & - & & & - & $"$ \\
\hline & $"$ & - & & & - & $"$ \\
\hline & $"$ & - & & & - & $"$ \\
\hline & $n$ & - & & & - & $"$ \\
\hline & $n$ & - & & & - & $n$ \\
\hline & $n$ & - & & & - & $"$ \\
\hline & $\operatorname{Dev}+\operatorname{Sp}\left(1-\operatorname{Tr}\left(\mathbf{R}^{2}\right)\right.$ & - & & & - & $"$ \\
\hline & $n(n)$ & - & & & - & $"$ \\
\hline & $t-\operatorname{Tr}(\mathbf{s e c})$ & + & & & - & $"$ \\
\hline & $a-T r+D e v+S p$ & + & & & - & $"$ \\
\hline & $a-T r+\operatorname{Dev}+S p+$ 䏣抽 (策急) & + & & & - & $"$ \\
\hline \multirow{4}{*}{$\begin{array}{l}\text { II } \\
(n=4)\end{array}$} & $a-T r+D e v+S p$ & - & 浑脂 & & & $"$ \\
\hline & $n$ & - & 헤: 染， & 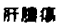 & & $"$ \\
\hline & $n$ & - & Gl 出血， & 肺类 & & $"$ \\
\hline & $"$ & + & 旰不全 & & & 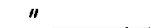 \\
\hline \multirow{4}{*}{$\begin{array}{l}\text { III } \\
(n=4)\end{array}$} & $\mathrm{a}-\mathrm{Tr}+\operatorname{Dev}+\mathrm{Sp}_{\mathrm{p}}\left(\mathrm{y}_{\mathrm{N}} \mathrm{e}\right)$ & + & Gi出血， & 模原照 & 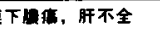 & 死 (行後 40日) \\
\hline & $(n)$ & + & Gl 出血, & 典腆谈 & ，呼吸不全, 旰不全 & $"(\| 15 E)$ \\
\hline & $a-T r+D e v$ & + & and & 沙水量 & . 肝不全 & $\|(" 759)$ \\
\hline & $S p+$ 䏣堣 & + & Gl 出血. & 四不全 & $\therefore$ 肝不全 & $u(" 65$ 日) \\
\hline
\end{tabular}

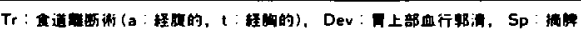

回著者らは，肝硬変による門元症に伴ら食道静脈瘤に 対する直達手術例に限り，術前の凝血能と術後合併症 発生，合併症による死亡との関俰を求め，凝固・線溶 系上り手術危険度を倹討した。

\section{I. 对象书よU゙方法（表 1)}

愛媛大学第 2 外科に入院し，術前に凝血学的検索が なされた肝硬変による食道静脈瘤患者21例を対象とし た。肝硬変は全例で術中あるいは術前の肝生検組織像 より判定した。これらを臨床的な術後合併症発生の有 無により，術後順調な絲過で回復した I 群（合併症非 発生群：13例), 術後合併症として重症浮腫, 重症創感 染, 肝膿湯, 消化管出血, 肺炎, 肝不全などが出現乙 たが，死亡に至らなかった第 II 群（合併症発生群：4 例）および重篤な合併症により死亡した III 群（合併 症死群：4 例）の3 群に分類した。なお食道静脈瘤の 手術においては, 術後 1 カ月以内に重篤な合併症によ り死亡する例もあるが，1 1 力を経過して後，徐々に 肝不全が進行し，その他の合併症も伴ない死亡するこ とも多いため，1 カ月以上経過した後，手術を契機に 病態が悪化し死に至った例も合併症死例とした。

さらに術後総ビリルビンがピーク時に $3.5 \mathrm{mg} / \mathrm{dl}$ 以 上に上昇した例を訹後黄㡺発生例之定義し，併わせて 検討した。な㭪後の一過性黄㾝のみをみた症例は疾 患の性質上，特に合併症として取り上げなかった，術 後黄疸は I, II, III 群でそれぞれ13例中 3 例 (23\%)，4 例中 1 例 (25\%)，4 例中 4 例 (100\%) に認められた。 また食道静脈瘤に対する術式としては，释腹的食道離 断に胃上部食道下部血行郭清，摘脾を併わせて行なら
一期的直達手術を原則としており，対象中 16 例 $(70 \%)$ に行なったが，経胸的食道離断術単独 1 例，経胸およ び経腹による 2 期的手術 2 例，摘脾非施行 1 例，摘脾 単独 1 例を行なった。これらの街前の凝血能をI〜III 群，術後黄疾の有無により比較検討した。

測定項目および方法・凝固・線溶系検査はおのおの 次の方法で行なった，i）活性化部分トロンボプラスチ ン時間（APTT)：カオリン添加法（sec）。 ii）ブロト ロンビン時間（PT）：Quick一段法（\%)，iii）血架 fibrinogen (Fbg)：比濁法 (mg/dl)。 iv) 血清 FDP： 帝国缄器社 FDPL テストによるラテックス凝集法 $(\mu \mathrm{g} / \mathrm{ml})$ ，v) 血 antithrombin III (ATIII), vi) 血 清 $\alpha_{1}$ antitrypsin ( $\alpha_{1}$ AT). vii) 血清 $\alpha_{2}$ macroglobulin $\left(\alpha_{2} \mathrm{M}\right)$. viii) 血清 plasminogen (plg)：いず れす一キスト社パルチゲンによる一元免疫拡散法 $(\mathrm{mg} / \mathrm{dl})$. ix) 血 $\alpha_{2}$ plasmin inhibitor $\left(\alpha_{2} \mathrm{PI}\right)$ : 第 一化学社テストチーム・アンチプラスミンによる比色 定量法 (\%)，x）末梢血血小板数 (plat)：コールター エレクトロニクス社自動血小板計数器 $\left(10^{4} / \mathrm{mm}^{3}\right)$.

なお正常値域は当科では，APTT：30４4sec, PT： $80-120 \%$, Fbg : $200 \sim 400 \mathrm{mg} / \mathrm{dl}$, FDP : $5 \mu \mathrm{g} / \mathrm{ml}$ 末満, ATIII : $24 \sim 34 \mathrm{mg} / \mathrm{dl}, \alpha_{1}$ AT : $190 \sim 400 \mathrm{mg} / \mathrm{dl}, \alpha_{2} \mathrm{M}$ : $180 \sim 400 \mathrm{mg} / \mathrm{dl}, \mathrm{Plg}: 10 \sim 20 \mathrm{mg} / \mathrm{dl}, \alpha_{2} \mathrm{PI}: 80 \sim 120 \%$, plat : $14 \sim 40 \times 10^{4} / \mathrm{mm}^{3}$ としている.

\section{II. 結 果}

1) 3 群の比較検討 (図 1，2）

全般的に I, II, III 群ともAPTT 延長, PT 低値, Fbg 低値，AT III 低値，Plg 低值，Plat 低值で，多くの症 

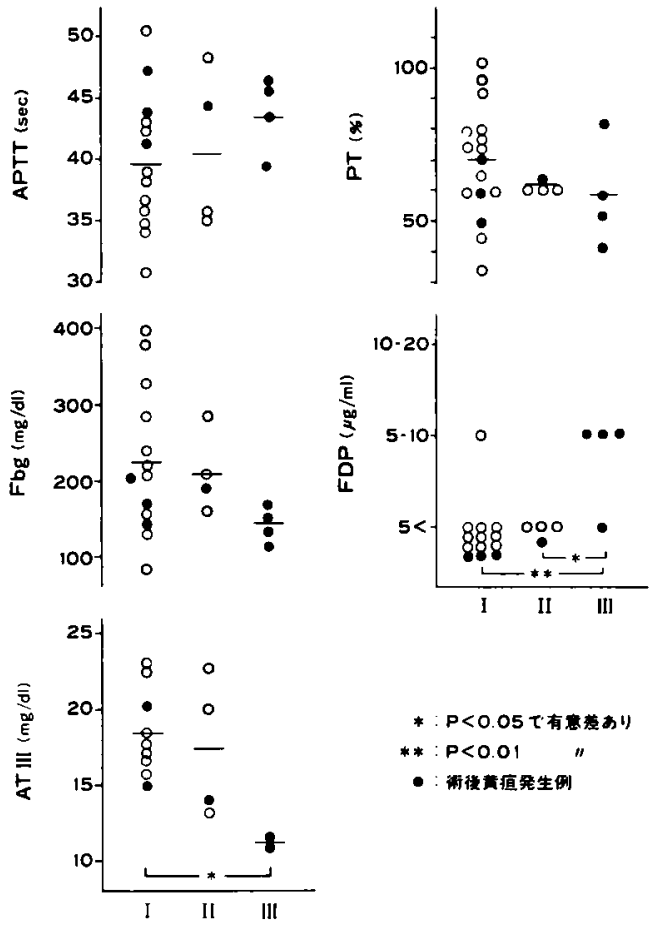

*: $P<0.05$ て有意差かり

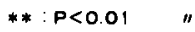

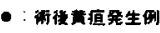

図 13 群の比較
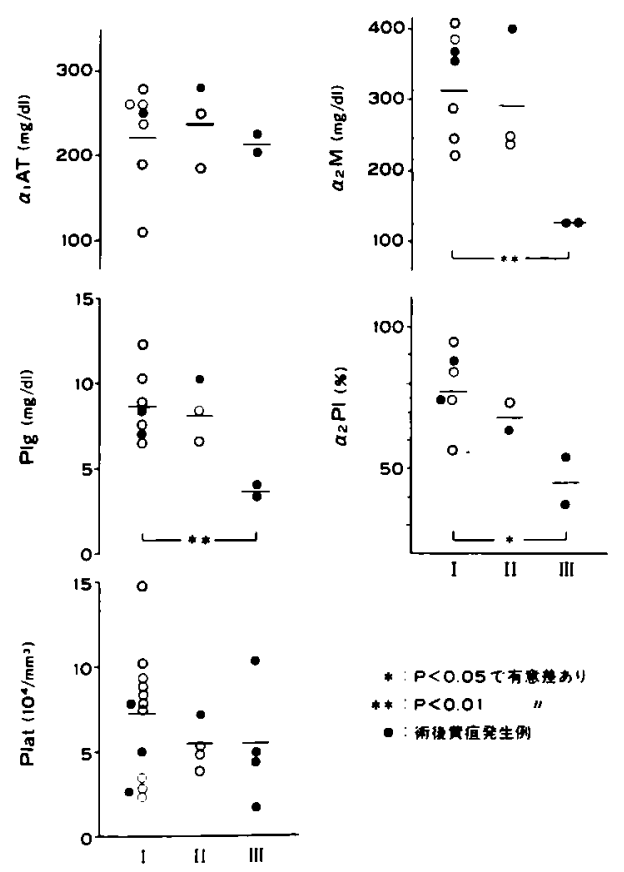

图23群の比較

例に凝血能の著しい異常が認められた。またIII群は I 群に比べ有意に FDP 高値 $(\mathrm{p}<0.01) ，$ ATIII 低値 $(\mathrm{p}<0.05), \alpha_{2} \mathrm{M}$ 低值 $(\mathrm{p}<0.01), \mathrm{Plg}$ 低値 $(\mathrm{p}<0.01)$, $\alpha_{2} \mathrm{PI}$ 低值 $(\mathrm{p}<0.05)$ の傾向が認められた。その他 PT, Fbg はIII 群でI 群より低いことが多かったが, 統計 学的有意差は得られなかった。またAPTT， $\alpha_{1} \mathrm{AT}$, Plat は両者の間で差は認められなかった。一方 I 群と II 群の間にはいずれの因子でも有意差はなく，ほぼ同 様な凝血能を示した，次に II 群と III 群の比較である が，III 群では II 群より FDP 上昇例が多かった（p< 0.05）他は有意差は得られなかったか，Fbg 低値， ATIII 低値， $\alpha_{2} \mathrm{M}$ 低値, Plg 低値， $\alpha_{2}$ PI 低値の傾向 がらかがえた。 ま FDP $>5$, AT III $<12 ， \alpha_{2} \mathrm{M}<200$, $\mathrm{Plg}<5, \alpha_{2} \mathrm{PI}<58$ の領域には III 群が含まれることが 多かった。

\section{2) 術後黄㾝の検討 (困 1，2）}

㭪後黄疸の有無により検討してみると，訹後黄連例 8例は非黄㡺例13例に比へ，有意に APTT 延長，Fbg 低値, ATIII 低値の傾向が認められた $(p<0.05)$ 。 ま た術後黄疸例では APTT $>44 ， \mathrm{PT}<60 ， \mathrm{Fbg}<170$, ATIII<15であることが多かった。

\section{III. 考 察}

肝硬変症例では凝固・線溶系の異常がみられること が知られて括り，検查成績では APTT延長，PT・ パプラスチンテスト・II・V・VII・IX・X 因子・ATIII・ $\mathrm{PLg} \cdot \alpha_{2} \mathrm{PI}$ などの因子の低下, VIII 因子増加，線溶六 進，血小板减少，血小板機能異常などが報告されてい， る(1 6). その成因としてはVIII 因子以外の凝固・線溶 系因子の大多数が肝で合成されていることより，肝で の産生低下が主因である，その他，全身的 $\mathrm{DIC}^{4) 77}$ ，脾 腫による血小板貯留早, 脾の類洞・側副血行路での LIC (Localized Intravascular Coagulation) ${ }^{910}$, 肝血流减 少・網内采機能低下による肝の凝固系物質等の種々の 代謝産物除去能低下”などす関係する。亦た吐血した 場合はそれに伴らショック，肝不全をはじめとする 種々の惦器障害, エンドトキシン血症などの臨床像に よっても修飾される ${ }^{12) .}$. 特に外科領域においては, 手術 による凝固・線溶系の変動がみられるばかりでなく， 肝硬变による食道静脈瘤の術後には特有な合併症によ る多烚器障害が発生することが少なからず，そのこと が疑血能に影響を与える。また近に多眼器障害に凝血 不全が誘発・増悪因子として深く関与することが知ら れている(2)13). 従って門穴症の術前後には凝血学的管 理が必要となる．今回肝硬変合併例にのみ限り検討し たが，術前はI〜III 群のいずれる凝血学的に著しい異 常をきたしていた。 
食道静脈瘤の術後には，肝不全，エンドトキシン血 症, ARDS 型肺合併症, DIC，消化管出血，腎不全，遇 延する発熱など種々の合併症が発生することが知られ ている(2). 本症例でも合併症のみられた II, III 群では, 消化管出血 8 例中 4 例, 感染 8 例中 4 例なとが合併症 ととしては多かった，感染症の合併が多いことは，肝 硬変による網内系失調を物語っている(2)14)。また術後 肝不全は門宇症においては数日から数週間かけて徐々 に増強する黄㡺を主体としたいわゆる intrahepatic cholestasis $^{15)}$ の型をとる．著者らの例でる III 群では 全例で徐々に黄㾝が増強し死に至っていた。

食道静脈瘤症例は何らかの基準により，治療方針を 選択する必要がある。これには従来より肝機能挨查よ りの報告は多くある ${ }^{122}$. 八木らは22), 直達手術適応の安 全限界値，危険值を，総ビリルビン，PT，へバブラス チンテスト，R15・ICG, KICG, 血清フルブミン上り求め た．その他，肝予備力を示すむのとして，糖負荷試験， クルカゴン負荷試験などの肝機能検查も有用であ $ろ^{(6)}$.

凝固・線溶系の蛋白は肝で生成される蛋白の中でも 半减期が短い rapid turn over proteinであり，その 時々の肝機能，特に蛋白合成能をみる上で有用で，肝 予備力を表わす。榑凝固・線溶系山網内系, 補体系, キニン系と密接に関係し17)，生体防御機構に役割を果 している(19)199. 従って疑血能を検索することは, 手術の 危険度を判定する上で有用であるすのと思われる。

しかしながら肝硬変による食道静脈瘤の手術危険度 と術前の凝血能との関係を詳細に調べた報告はみられ ない. 本成綪では APTT 延長, Fbg 低值, ATIII 低值 例，特に APTT $>44 \mathrm{sec}, \mathrm{PT}<60 \%, \mathrm{Fbg}<170 \mathrm{mg} / \mathrm{dl}$, ATIII $<15 \mathrm{mg} / \mathrm{dl}$ の症例で術後黄㾝発生例が多かっ た。さらに合併症死したIII群は合併症のみられな かった I 群に比へ，FDP 高値，AT III 低値， $\alpha_{2} \mathrm{M}$ 低 値，Plg 低值， $\alpha_{2}$ PI 低値の傾向が認められた。 また㭪 前に FDP $>5 \mu \mathrm{g} / \mathrm{ml}$, AT III $<12 \mathrm{mg} / \mathrm{dl}, \alpha_{2} \mathrm{M}<200$ $\mathrm{mg} / \mathrm{dl}, \mathrm{Plg}<5 \mathrm{mg} / \mathrm{dl}, \alpha_{2} \mathrm{PI}<58 \%$ の例は III 群である ことが多かった。これより，術前の凝血能は術後黄疸 発生，耐術の可否などの判定に参考になるもの之考兄 られる.一方合併症は発生したが耐術し得た II 群と前 述のI群の間には差がなかったことより，凝血能は術 後合併症か成生するか否かといらことよりるむしろ， その合併症に耐之得るか否かといら事を反映するるの と思われた。しかしながら III 群は緊急手術例が多く， 術前の出血，輸血などが凝血能に悪影響を及ぼしてい
表 2 挰血学的検查值よりみた手術危除度

\begin{tabular}{|c|c|c|c|c|c|c|c|}
\hline & APTT & PT & Fbg & FDP & AT III & $\mathrm{Plg}$ & $a_{2} P I$ \\
\hline $\begin{array}{l}\text { 安全域 } \\
\text { (合伊症竟生(一)) }\end{array}$ & $<40$ & $>70$ & $>200$ & & $>16$ & & \\
\hline 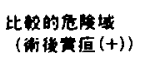 & $>44$ & $<60$ & $<170$ & & $<15$ & & \\
\hline 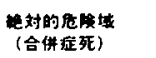 & & & & $>5$ & $<12$ & $<5$ & $<58$ \\
\hline
\end{tabular}

るとも考えられる、このような凝血学的に耐術不能と 思われる症例は，状態が許せば手術時期を遅らせ，凝 血能の改善をみてから待機的に手術を行ならか，ある いは硬化療法などの非手術的療法を一時行ならなどの 治療方針の再検討を要するるのと考えられた。

以上より肝硬変に上る食道静脈瘤直達手術におい て, 術前凝血能は術後黄㡺発生, 耐術の可否の判断に 有用であった。 またいまだ症例は少ないが，今回の検 討より表 2 に示す如き，手術の安全域，比較的危険域 (衍後黄㾝発生), 絶対的危険域 (合併症死) が挙げら れ，食道静脈瘤の手術の危険度を判定する上で有用で あるものと考えられる。

$$
\text { まとめ }
$$

肝硬变による食道静脈瘤の直達手術に括ける術後黄 疸をはじめとする合併症発生, 手術危険度を術前凝血 能より検討し，次の結語を得た。

1）食道静脈瘤患者はいすれも著しい凝血学的異常 にあったが, 㭪後黄疸発生例では APTT, Fbg, AT III なとに，合併症死例では FDP, AT III, $\alpha_{2} \mathrm{M}, \mathrm{Plg}, \alpha_{2}$ PIなどがより異常値をとった。

2）手術安全域は AP TT $<40 \mathrm{sec}, \mathrm{PT}<70 \%, \mathrm{Fbg}>$ $200 \mathrm{mg} / \mathrm{dl}, \mathrm{AT}$ III $>16 \mathrm{mg} / \mathrm{dl}$, 比較的危険域（術後黄㾝 発生) は APTT $>44 \mathrm{sec}, \mathrm{PT}<60 \%, \mathrm{Fbg}<170 \mathrm{mg} / \mathrm{dl}$, AT III $<15 \mathrm{mg} / \mathrm{dl}$, 絶対的危険域（術後合併症死）は FDP $>5 \mu \mathrm{g} / \mathrm{ml}$, AT III $<12 \mathrm{mg} / \mathrm{dl}, \mathrm{Plg}<5 \mathrm{mg} / \mathrm{dl}, \alpha_{2}$ $\mathrm{PI}<58 \%$ といら線を一応の基準とした。

以上より術前凝血能は, 術後黄疸発生, 耐術の可否 の判定に有用であると思われる。

\section{文献}

1) Child, G.G.: "Portal Hypertension", 1974, W. B. Saunders, Philadelphia, 000.

2）八木義弘，杉浦光雄：肝障害例の消化器系手術 一閏脈王六進症に対する直達手術例の検討, 日消 外会誌，15：706-711，1982.

3）山科昭雄：肝疾患における血液凝固能に関する実 験的・臨床的研究。肝䁍, $17: 425-443,1976$. 
4) Verstrete, M., Vermylen, J. and Collen, D.: Intravascular coagulation in liver disease. Ann. Rev. Med., 25 : 447-455, 1974.

5) Hendrix, T.R. : The hemostatic defect of liver disease. Gastroent., 60 : 108-119, 1971.

6）前川 正：肝硬変症における凝固異常とDIC，汎 発性血管内血液凝固症 V. 昭和56年度業績報告, 小 宮正文編，1982， p. 26-36.

7) Tytgat, G.N., Collen, D. and Verstraete, M.: Metabolism of fibrinogen in cirrhosis of the liver. J. Clin. Invest., 50 : 1690-1701, 1971.

8) Aster, R.H.: Pooling of plaeelets in the spleen: Role in the pathogenesis of "Hypersplenic" Thrombocytopenia. J. Clin. Invest., 45 : 645-657, 1966.

9) Gerrits, W.B.J., van Aken, W.G. and van der Meer, J., et al. : Splenomegaly associated with chronic consumptive coagulopathy. Acta Med. Scand., 195: 425-430, 1974.

10) Kamisasa, I., Hidai, K. and Sugiura, M., et al. : Effects of splenectomy on blood coagulation and fibrinolysis in patients with liver cirrhosis: Possible role of the spleen in haemostasis. Thrombos. Haemostas., 42 : 1529-1535, 1979.

11）中尾昭公，市原透，酒向猛他：肝における plasminoge activator $\omega$ clearance mechanism について, 外科診療, $21: 1157-1164 ， 1979$.
12）横田峻,河野幸裕, 奈良政信他：肝手術之肝網内 系, 日消外会誌，13：933-938，1980.

13）佐藤元通，喜安佳人，大越輝紀他：消化器手術前後 の血浆 antithromjbin III の推移, とくに多臟器障 害発生との関係について，外科と代謝・栄義，16： 543-551, 1982.

14) Norton, L., Moore, G. and Eiseman, B. : Liver failure in the postoperative patient: The role of sepsis and immunologic deficiency. Surgery, 78 : 6-13, 1975.

15) Schmid, M., Hefti, M.L. and Gattiker, R.: Benign postoperative intrahepatic cholestasis. N. Eng. J. Med., $272:$ 545-550, 1965.

16）有井滋樹，高三秀成，戸部隆吉：術後肝不全, 手術, $36: 1169-1179,1982$.

17）青木延雄, 諸井将明: 生体内蛋白分解醉素阻害物 質一その生物学的・臨床的意義，代謝，14： 1099-1111, 1977 .

18）平㳯博之, 小林弘忠, 田烟陽一郎他：一パンによ $る$ reticuloendothelial system (RES) phagocytic activity の賦活, 医学のあゆみ, 121：194-197, 1982.

19) Davidson, R.K., Cardenas, A. and Busuttil, R. $W$.: The effect of heparin and low molecula $r$ weight dextran on survival after fibrinopurulent peritonits. Surg. Gynecol. Obstet., $153: 327$ $-331,1981$. 